Instructions for authors, subscriptions and further details:

\title{
Black Masculinity and Plantation Patriarchy in Margaret Walker's Jubilee
}

Agnieszka Łobodziec ${ }^{1}$

1) Univerisity of Zielona Gora, Poland

Date of publication: June $21^{\text {st }}, 2015$

Edition period: June 2015-October 2015

To cite this article: Łobodziec , A. (2015). Black Masculinity and Plantation Patriarchy in Margaret Walker's Jubilee. Masculinities and Social Change, 4(2), 123-143. doi: 10.17583/MCS.2015.1413

To link this article: http://dx.doi.org/10.17583/msc.2015.1413

\section{PLEASE SCROLL DOWN FOR ARTICLE}

The terms and conditions of use are related to the Open Journal System and to Creative Commons Attribution License (CC-BY). 


\title{
Black Masculinity and Plantation Patriarchy in Margaret Walker's
}

\section{Jubilee}

\author{
Agnieszka Łobodziec \\ Univerisity of Zielona Gora, Poland
}

\section{Abstract}

In Jubilee, Margaret Walker depicts plantation patriarchy as a racial and gendered context that coerces black men to redefine their masculine conceptualizations. The fictitious slave plantation represents the system which commodifies and divides black people "into those with skills [...], field hands, 'breeding females,' concubines, and children" (Nichols, 1972, p. 10). This portrayal of slave plantation is congruent with historically documented circumstances, when "Much of [the slave] labor was gender- or age- specific" (Ash, 2010, p. 20). As far as the position of black men is concerned, ascribed a subordinate status to that of white masters, overseers, and servants, both free and enslaved black men begin to imbibe patriarchal mindset and redefine their own masculine prowess. As Margaret Walker portrays, this response to oppressive plantation patriarchy effects multifarious black male postures, ranging from resisting and self-asserting warriors to humiliated and silenced victims.

Keywords: plantation patriarchy, gender roles, black men, emasculation, masculine affirmations 


\title{
Masculinidad Negra y Patriarcado de Plantación en Jubilee de Margaret Walker
}

\author{
Agnieszka Łobodziec \\ Univerisity of Zielona Gora, Poland
}

\section{Resumen}

En Jubilee, Margaret Walker muestra el patriarcado de plantación como un contexto desmarcado por el género y la raza que obliga al hombre negro a redefinir sus conceptos de lo masculino. La plantación de esclavos en esta obra de ficción representa al sistema que mercantiliza y divide a los negros "en quienes tienen habilidades [...], mano de obra para el campo, 'hembras reproductoras', concubinas y niños" (Nichols, 1972, p. 10). Este retrato de la plantación de esclavos se corresponde con las circunstancias que han sido documentadas en la historia, cuando "buena parte de la mano de obra [esclava] se especificaba según el género o la edad" (Ash, 2010, p. 20). En lo que respecta a la posición del hombre negro, la cual estaba subordinada a la de los amos blancos, la de los capataces y la de los sirvientes, tanto los hombres negros libres como los esclavos comenzaron a absorber la mentalidad patriarcal y a redefinir su propio coraje masculino. Como lo plantea Margaret Walker, esta respuesta al patriarcado opresor de las plantaciones determina múltiples facetas de las posturas del hombre negro, que van desde el guerrero desafiante y dominante hasta la víctima humillada y silenciada.

Palabras clave: patriarcado de plantación, roles de género, hombre negro, castración, afirmaciones masculinas 


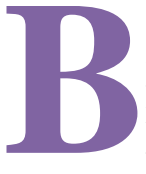

ell Hooks labels the peculiar system of slave plantations as plantation patriarchy (2004, p.1). The slave plantation reconstructed by Margaret Walker in Jubilee indeed testifies to the plantation's patriarchal nature. Black male characters' responses to their inferior status encompass negotiation of twofold conceptualization of patriarchy, which can be divided into oppressive and benevolent expressions of masculine dominance. The former entails violent, humiliating exercise of white male power; the latter involves a caring, protective posture. The White slaveholders and overseers function as the dominant patriarchal subjects oppressive towards their objects: black men and women. On the other hand, in relation to their own wives and families, white men seek to act as benevolent patriarchs. Black men, in turn, are unable to fulfill patriarchal roles within the confining circumstances. Nevertheless, despite a general sense of powerlessness, some black men still seek to establish a harmonious family life, founded on a gender role division.

\section{Oppressive Patriarchal Nature of Slave Plantation}

Margaret Walker in Jubilee portrays slave plantation as a structure that secures white men's power and control over human merchandise embodied by black enslaved people. The white master, J. Morris Dutton, epitomizes a white capitalist, patriarchal slaveholder, who affirms his alleged superiority over black men.

First of all, J. Morris Dutton's father inculcates in him capitalist, oppressive, patriarchal ideals, which constitute a fundamental point of departure for growth towards manhood. The Dutton men aspire to the Southern Euro-American conventions that "delineated models of the ways in which women and men lived as members of a gender" (Fox-Genovese, 1988, p. 196). According to these models, a man, "the cavalier or gentleman, was strong, masterful, quick to anger, ready with his pistol, sometimes too fond of liquor, but, withal, chivalrous and protective of those who accepted the legitimacy of his claim to command" (ibid., p. 197). Correspondingly, as a young man, Morris particularly enjoys hunting, a typically masculine activity. In later years, he reminiscences about the "good times he had [...] when he was just a slip of a lad and his father took 
him coon hunting at night with the hounds, slaves, patter-rollers, and all!" (Walker, 1999, p. 33). Hunting offers an opportunity of sharing time with his socially influential and recognized father, which supposedly increases Morris' masculine self-esteem. It is also an occasion where the slaveholderto-be is shown the inferior position of black slaves, who are regarded on the hunting trip as being on the same level as dogs, or lower, when one thinks of dogs as man's best 'friends.' The most powerful and, expectedly, wisest man in charge of hunting is his father. Moreover, supposedly, through hunting, the young boy gets accustomed to weaponry, a feature associated with masculine toughness and power.

Another source of Morris' pride lies in his father's historic and awarded involvement in the American Revolution, where he fought with George Washington. Afterwards, his father was awarded a considerable honorarium for his service as a model soldier, which presumably enabled him to expand his own father's plantation. Finally, as an heir of his "mother's holdings and his father's father's land" (ibid., p. 34), John Morris becomes one of the most affluent planters. Therefore, having been raised in a realm constructed along patriarchal role models, John regards the maintenance of the patriarchal tradition within his household as his inherited duty. At one point, while looking at his ancestors' portraits, he thinks, "Every time I look at them I think they are telling me to uphold the honor of this house. I have inherited their responsibility just as my son will inherit the honor of this house when I am dead" (ibid., p. 182). Attaining honor means to hold on one's power and dominance. Slavery, as reconstructed in the novel Jubilee, facilitates the realization of this patriarchal objective.

Above all, Morris attains a respectable position in the broader society as the owner of a prosperous plantation. His considerable assets assure political career. He knows he possesses "enough slaves to give him a large number of votes. For every five slaves he could count three votes" (ibid., p. 32). His involvement in politics also excites his wife, Big Missy, who hopes to socialize with more dignified persons. "Perhaps now that John was coming up in the political world their social life would be greatly expanded" (ibid., p. 73). According to her expectations, influential white men gather at Morris' house in order to converse on "the news and the crops and the weather, their slaves, and the politics of the country, the state, and the nation" (ibid., p. 75). At social meetings, the white men also 
express mutual male solidarity; "After dinner, over brandy and cigars, with the ladies once more out of earshot, the men began congratulating John Morris Dutton on his recent election to the state legislature and joking with him over his political future" (ibid., p. 77). Further, since active engagement in political life determines one's masculine power, at the age of fifty-seven, Morris takes pride in his fifteen-year-long membership "in the House of Representatives of the Georgia Legislature” (ibid., p. 177).

White male political engagement also helps to maintain the sanctioned slavery system. In pursuit of personal and political objectives, white slaveholders continue to regard black slaves as objects. At the gatherings within the Morris' home, they reference their black slaves as inferior beings, a property that has to be controlled and cared for and that is expected to expand profits. One of the men states, "Corn as fine as any in the country, more than enough to feed all my mules and nigras through the winter" (ibid., p. 76). Another man points out, "I haven't had much trouble this year, but a lot of my nigras have been sick and sometimes last winter as many as eight and ten a day were out of the fields, laid up and couldn't work, or wouldn't work, I don't know which" (ibid., p. 75). A third man calls a forty-five-year old black male slave a 'boy.' Anyway, most men, including John Morris, complain about their black slaves' illness, thus their inability to efficiently perform arduous tasks. They do not express any concern regarding the causations of the slaves' diseases and the potential threat to their health or life. Moreover, the white males seek ultimate power over the black slaves, which, they believe, is the confirmation of the natural bifurcation between the so-called master race and the slave race. Accordingly, Judge Ezra Winston contends,

I'm afraid we are in for some more battles on the national issues and for the protection of our natural rights here in the state of Georgia [...] Such as our sacred way of life, our agricultural system, classic culture, with the natural divisions of mankind into servile and genteel races (ibid., p. 79).

All things considered, John Morris holds gatherings of influential white men because he is aware of their political power, which can secure his career. "The election was a mere formality; of course he had won. His guests tonight, together with himself, were the richest planters in central 


\section{Agnieszka Łobodziec - Black Masculinity and Plantation}

Georgia and they controlled, both politically and financially, a third of the state" (ibid., p. 78).

Apart from being political, the oppressive plantation patriarchy had also a sexual dimension as he historian Darlene Clark Hine observes,

The scholarly consensus is that at least 58 percent of all slave women between the ages of fifteen and thirty were sexually abused by white males. Rape had the added advantage of producing new slaves and thus enriching masters while satisfying white men's carnal desires. Perhaps the most daunting task confronting black women historians is to persuade students of slavery to see it as more than an economic institution. Slavery was also a sexual institution, and it was white male control of black women as sexual beings that shored up the patriarchal dimension of the system. (1996, p. 36)

There are a number of reasons for this brutality. First, there is the sexual deviancy of white men conditioned by racialized fetishization. In Jubilee, John Morris utilizes his slave Hetta as an object to satisfy his sexual lust. He remembers "how she had looked growing up [...] Her small young breasts tilted up, and even her slight hips and buttocks were set high on her body" (Walker, 1999 p. 8). Secondly, by abusing a black woman sexually, the young man "with hot blood in his veins" (ibid., p. 7) can satisfy his sexual proclivities before marrying a white lady. He develops such stance under the influence of his father, who once instructed him that "it was better for a young man of quality to learn life by breaking in a young nigger wench than it was for him to spoil a pure white virgin girl. And he had wanted Hetta, so his father gave her to him, and he had satisfied his lust with her" (ibid., p. 8-9). Later, John Morris marries Salina, a young lady from Savanna. He discovers she is sexually frigid as she considers procreation the only proper instance of sexual intercourse, something she does not want to experience again after birthing two children. At this point, Salina epitomizes the Southern gentlewoman, expected to be "innocent of any hint of hunger, temper, or passion" (Fox-Genovese, 1988, p. 197). In such circumstances, in order to satisfy his passion, John Morris continues to force himself upon Hetta. The extramarital affair not only brings sexual satisfaction but it also serves to reproduce the slave labor force. Therefore, when John Morris fathers children from his black slave, he does not 
formally acknowledge parenthood. Instead, he humiliates a black slave man whom he appoints as the children's surrogate father. He does not find fathering children of the black woman particularly troublesome. "When she began having babies, it was no problem. He gave her Jake for a husband and that was that" (Walker, 1999, p. 9). Engaging his patriarchal power, he decides on the nature and structure of slaves' familial life.

Another means of maintaining white patriarchal dominance is participation in the Civil War. First of all, in sync with "the citizen-solder ideal" (Parker, 2009 p. 67), most southern white men regard enlistment as the affirmation of masculinity. For instance, Johnny, John Morris Dutton's son, takes pride in his graduation from West Point, becomes interested in politics, enlists into the cavalry, and believes his engagement in the Civil War is his mission. He views all the aforementioned undertakings and achievements as evidence of his masculinity. On the battlefield, Johnny reveals an obsession with masculine power.

In fact, the flashing guns exhilarated him and he felt the blood racing hot in his face. He came alive on the battlefield. He always kept a cool head, and he was alert in all his movements. In a way, he felt himself unusually fortunate. He was born into a class of men who naturally took the role of leadership in this war (Walker, 1999, p. 216).

He sees his martial abilities and expertise with weapons as traits of his southern patriarchal heritage.

Another class of white men that plays a significant role within the plantation patriarchal order is composed of the overseers. In Jubilee, the white overseer, Grimes, seeks to exercise power and to establish a prosperous household. Above all, his dominance over slaves is a way by which he affirms his higher status over at least one group of the social ladder. He belongs to the lowest white social class, often referred to as "poor white trash," or "po buckra" (ibid., p. 60). The group inhabits an area of unproductive, hilly land, relatively far from the slaveholders' mansion. Actually, Grimes lives "in circumstances not much better than the slaves. His house [is] slightly better than the Negro Quarter houses on the plantation, and his wife, Janey, [is] only an indifferent housekeeper" (ibid., p. 60). Nevertheless, Grimes hopes to better himself, "to have a farm of his 


\section{Agnieszka Łobodziec - Black Masculinity and Plantation}

own" (ibid., p. 27) and to spend more time fishing and hunting as the plantation owner does.

In the meantime, the slave plantation offers an arena where the overseer has an opportunity to exercise masculine power through violent oppression of black people. "His job of driving niggers kept him on the run" (ibid., p. 60). Several instances evidence excessive violence. Firstly, when he discovers that meat has disappeared from a smokehouse, he becomes homicidal. He says, "If I could only find the nigger that done it, I'd killed him" (ibid., p. 63). He examines the slaves' cabins at lengths, searching for suspects and "threatening to beat every nigger involved and shoot the ringleader" (ibid., p. 64). Secondly, Grimes brutally kills the elderly man named Grandpa Tom, who objects to using the plantation master's wellbred horses as mules in the fields. He also helps in murdering other elderly slaves, Uncle Plato and Uncle Esau, whom he commands to labor in the fields. He regards them as useless because they collapse after less than one hour of picking cotton in scorching heat. Maliciously, Grimes forces them to enter the old house that Grimes' guards set fire to. Without investigation, the death of the men is referred to as "accidental" (ibid., p. 135).

To sum up, in Jubilee, Margaret Walker envisions the manner in which white slaveholders and overseers commodity and emasculate black enslaved men. They disregard the humanity of black slaves, whose only role is to serve as an efficient labor force.

\section{Free black men's response to plantation patriarchy}

In Jubilee, Margaret Walker depicts the influence of plantation patriarchy on both free and enslaved black men. The manner in which the male characters respond to patriarchal practices depends on the extent to which they realize their capability of fulfilling patriarchal roles and, by this means, affirm their masculinity. It is obvious that a free black man manifests more hope, positive self-esteem, and sense of self-sufficiency than enslaved black men. Nevertheless, the legal system and white supremacy aim to impede both free and enslaved black men's independent agency.

The character Randall Ware epitomizes a free black man who aspires to realize patriarchal roles. Nevertheless, the established slavocracy and oppressive patriarchy delimit his freedom. First of all, white patriarchs find 
black male freedom threatening and undesirable. They fear disruption of the racially hierarchical order on the plantations, which free black men could initiate through encouraging black slaves' resistance, rebellion, and even insurrection. For this reason, white men approach Randall Ware's employment at the Duttons' plantation as a blacksmith with reservation.

Rarely, indeed, did a free Negro come on the place to work. The overseers were afraid of the trouble free Negroes might make among the slaves, but there had not been a blacksmith on the place for a long time, so this man had been brought in from the nearby village where he owned his own smithy (ibid., p. 87).

In fear of the free black man's disruption of the plantation order, whites implement certain laws that delimit the black man's freedom, as the following fragment relates:

As a free man in Georgia, Randall Ware had his troubles. The law was strict in the surveillance of all blacks, and the free black man was only slightly better off than the slaves. His movements were proscribed and all his actions defined. His legal status was flimsy because he must always have a white guardian. This white guardian must be a property owner of some means, and technically, the free man was attached to the land of his white guardian in much the same manner of a serf or slave. His status was also similar to that of an indentured servant whose time was not his own. (ibid., p. 92)

Quasi-independent, Randall Ware has to have a white guardian. Fortunately, he develops a friendly relationship with a white man, who is an abolitionist and who even "willed this young black friend much of his property" (ibid., p. 91). On the other hand, although he becomes the owner of considerable property, owning a piece of land, a shop, and a workshop, the state financially benefits from his status and from his income because, every year, it compels him to "renew his free papers by paying an exorbitant tax which increased annually" (ibid., p. 92). Additionally, he has to have a certain amount of income in order to register as a free man and has a "difficulty in owning firearms [similarly to] a slave or an Indian" (ibid., p. 92). All things considered, a free black man does not possess the same privileges as a free white man does. As a matter of fact, he is a 


\section{Agnieszka Łobodziec - Black Masculinity and Plantation}

second-class citizen, who has to act according to discriminating rules forced upon him by white men.

Another area where a black man's freedom is limited is in regard to family life. No matter how much he loves an enslaved black woman, he is not allowed to freely marry her, because she belongs to her white master. Paradoxically, Vyry is a daughter of her slave master John Morris Dutton, a free white man. Nevertheless, she does not inherit her father's status. According to the law, she is "tied to slavery by a black mother" (ibid., p. 93). Randall Ware knows that "as a mulatto, by Georgia law she could be free to marry a free man with her master's consent, that is, if she could get that consent" (ibid., p. 93). In such circumstances, Randall has only two alternatives: either to attempt to buy Vyry from her master or to abscond with her. He realizes the former will be very difficult, if not impossible, and the latter would be illegal. Seeking to independently fulfill the role of benevolent patriarch, initially he does not consider fleeing with Vyry. With considerable money at his disposal, he hopes to purchase her.

He reassured himself that he could be confident that gold would buy anything on the market. His money had always been powerful enough to buy anything he wanted. Surely it would be powerful enough to buy the object of his heart's dearest desire (ibid., p. 93).

Unfortunately, against his expectations, Vyry's master does not want to sell her. Further, he faces another dilemma engendered by white plantation patriarchy, which deprives him of the right to formally claim paternity to a child whose mother is a slave. "Now they would have a child in the spring and this child would not be free either. This child would belong to Marster" (ibid., p. 141). No matter how much Randall and Vyry try to break free, Vyry's white master asserts his power over the black family. When Vyry asks Morris for permission to marry a free black man, he immediately reproaches her, claiming ownership of Vyry and her child. Infuriated, he exclaims,

Getting a child by you don't make him own you nor own the child. I own you, and I own your unborn child. When you ask me to let you marry a free-issue nigra you ask me by the law of the state of 
Georgia to set you, a mulatto woman, free, and that's a mighty lot to ask (ibid., p. 144).

Therefore, the law places Randall Ware in a subordinate position as husband and father of his enslaved wife and child. It is the white man who is the "master of his situation, and he knew it" (ibid., p. 145). Afterwards, Randall Wares' “own position became more dangerous and more insecure. There were loud, open threats against the free black man, and the threats to his freedom [...] Georgia was considering a law to regulate free men" (ibid., p. 153). One day Randall has to flee the South.

\section{Enslaved black man's mute response to emasculating plantation patriarchy}

In Margaret Walker's Jubilee, the character of Jake represents a subjugated, helpless black enslaved man, unable to resist white oppressors. He does not have the power over his family life, over which he would like to act as a benevolent patriarch. First of all, his slave master choses an enslaved black woman as a spouse for him, determining his marital status. Jake is given Hattie after his master Morris John Dutton has sired children with her. Since Dutton does not want to formally recognize paternity to the children, he selects a black enslaved man as their surrogate father. This undertaking has another humiliating dimension. Jake opines, "Marster had broke her in, and then "give her to me"" (ibid., p. 14). According to patriarchal conventions, the black man should have sexually initiated his wife. The white male usurps this convention as he regards the black man's wife as an object of his own sexual lust. The abuse is not only premarital but it also continues when Jake and Hattie are married. The master's intervention into Jake's martial life constitutes a tremendous emotional challenge. At one time, Jake feels a "bitter dry taste in his mouth" (ibid., p. 14) when he finds out that the white enslaver visits Hetta, while Jake labors in the field. At another time, he feels devalued, suspecting his wife might consider "herself too good for him" (ibid., p. 14) because of her forced concubinage with the white master. Therefore, not only is he a husband deprived of his right to oversee his family life but also he is continuously besought by conflicting emotions. 


\section{Agnieszka Łobodziec - Black Masculinity and Plantation}

Secondly, Jake cannot assert his manhood as the legitimate father of his own and those of his wife's children. One reason is the fact that his wife gives some of the children away to the white enslaver, who does not express any fatherly concern about them but regards them just as additions to his slave free labor force. Thus, the master has the right to sell them at any time. This literary portrayal alludes to the actual menacing circumstances surrounding the black family, in which "Few slave children ever knew their fathers or enjoyed the love and care of both parents" (Nichols, 1972, p. 15). Knowing this, no wonder then that Jake refrains from expressing his feelings towards the children, not to mention future plans concerning them. His speechlessness and seeming disaffection are a kind of survival strategy. Deeper emotional engagements would be unendurable in a situation where he does not have the right to bring up his own offspring.

As a result of emotional repression and the sense of emasculation, Jake remains silent in a number of humiliating, painful, and helpless circumstances. When, at the age of twenty-nine, Hetta dies after birthing her fifteenth child, Jake says "nothing, as usual, and Marster only laugh[s]" (Walker, 1999, p. 6). While most slaves stand around Hetta's bed, Jake remains in a corner, "where he could look behind the quilt" (ibid., p. 11). Actually, Hetta's intense suffering affects him deeply and he walks out of the cabin. The only thing he can utter is "a terrible groan" (ibid., p. 13). He feels like withdrawing entirely from the death scene. "He wanted to go off alone in the woods or work in the fields and not be here when Hetta died" (ibid., p. 14). On the whole, Jake's silent withdrawal evidences awareness of an inferior status to that of his white master, something he cannot oppose. $\mathrm{He}$ is a dehumanized and emasculated man, as the following passage relates:

Jake's path seldom crossed Marster's. He stayed out of his way as much as possible, but if by chance they ever came face to face, Marster laughed and slapped Jake's back and talked down to his slave, Jake, like he did to one of his good hound dogs. Jake hated Marster and despised himself and looked at Hetta and got mad and evil. But that was the end of it. He never dared say anything or do anything about it. (ibid., p. 14-15) 
Further, the fusion of pent-up rage, self-contempt, and hopelessness renders emasculated Jake strangely indifferent towards his status of 'property,' a thing belonging to his master. He ironically contends, "Well, now she is dying, and they'll send me away [...] Guess in a way I am glad to get away from here. Marster's always said he'll get a fair price for a good stud like me" (ibid., p. 15). Jake is aware that after Hetta's death his master has no more use for him and he is going to be sold away. The only thing that temporarily troubles him is his son's future. He inquires, "What would they do with his helpless black child then" (ibid., p. 14). Thus, whatever thoughts cross Jake's mind, they express the sense of helplessness and hopelessness of a black enslaved man, unable to affirm his manhood and humanity on a white plantation.

Other instances of the silent response of black males to white male oppression relate to the enslaved men's inability to express rage due to paralyzing fear. From a very young age, black men are forced to repress their contempt towards the white male brutality, which is utilized as a means to secure the enslaved men's submission and obedience towards their white oppressors. Emasculated slave boys stand numb while the black woman Lucy is severely whipped, as punishment for attempting to run away. The black boys are just "lounging around with solemn expressions on their faces" (ibid., p. 113), while the tortured black woman is "twitching all over and foaming at the mouth" (ibid.). Further, when the overseer Grimes orders the guard, using a piece of heated iron, to burn the letter "R," which stands for runaway slave, on Lucy's face, the slave boys "tremble in terror" (ibid., p. 114) and cry out, "Mister Grimes I feels awful sick to my stomach!" (ibid.). At the same time, the black men know that they do not possess the power to protect the black woman, because the slave master, overseer, and guards have the ultimate, unquestionable authority over them.

More horrendous than torture, the lynching of black women renders the paralyzed black men speechless. Paradoxically, what the black slaves regard as horrific white masters approach as festive. The slaveholders arrange the lynching of two black women sentenced for murder on the fourth of July to celebrate national Independence Day. They order their cooks to prepare plentiful food since the hanging is going to be the peak of the picnic. The slaves, on the other hand, wonder, "How you reckon we will swallow over a hanging?" (ibid., p. 119). Interestingly, it is predominantly 


\section{Agnieszka Łobodziec - Black Masculinity and Plantation}

white men who are most excited about the execution. "Up in the tress were perched a number of whites, chiefly boys and young men who heckled the crowd, calling out obscenities and insulting jokes" (ibid.). When it comes to slave owning families, many of them are "represented by the men only" (ibid.). The terrified black people remain silent. The authorities in charge of the execution are also white males. They approach the death scene as a board of dignified patriarchs.

Exactly on the stroke of twelve noon the judge came out in his black robes and with him the preacher, also in black robes, and the two women prisoners in chains between their guards [...] With them also were county officials. The hangman sat like a hawk, perched on a stool, also wearing the blackest black (ibid., p. 120121).

They hope the execution will be an effective warning directed to other black slaves who plan on insurrection, poisoning, or any other violent act against their masters. Indeed, all the black people are "frightened and sickened out of their wits" (ibid., p. 125) by the view of two black women hanging' one "throttled with her eyes popping and bulging and her tongue forced out and hanging in plain view of the crowd" (ibid., p. 124). While black children scream and their mothers faint in response to the barbaric executions, black men exhibit peculiarly paralyzing postures of insanity, as "on the faces of some of the men and boys there was an unnatural look, neither human nor sane, a look of pleasurable excitement, a naked look of thrills born from cruel terror" (ibid., p. 125). The black men's silent response results from a sense of shock and awe. They know they cannot aid the women, who, having committed the act or not, are seen by slaves as models of resistance to the slavery's brutality. They feel incapable of fighting the white men who refer to the women as unforgivable sinners and "black bitches" (ibid., p. 124). With their rights abrogated by Black Codes "tightening the control of master over slave" (ibid., p. 49), they can only watch, as they are stunned into silence by the horror before them.

In summary, the characters who do not actively oppose white oppression, represent black men who are overwhelmed by the emasculating system of slavery, which inculcates within them the conviction that they are socially inferior. "This is what the idea of race achieved. In the situation the 
idea of race did not exist merely to effect a separation between peoples; it did this incident to its major function of control" (Thompson, 1975, p. 116). In the process of ascribing certain, opposing, features and roles to black and white people, "It was not sufficient to assert the superiority of the white man and the inferiority of the black man; it was much more important to persuade the black man to accept the allegation of his own inferiority" (ibid., p. 116). The inferiority that the selected literary characters have internalized has more of a social dimension than an ontological one. Moreover, it is brought on by a sense of social powerlessness rather than by black male acceptance of their inferiority.

\section{Black men's resistance to oppressive plantation patriarchy}

Margaret Walker also projects the characters who resist the white male oppression, in contradistinction to the mute and submissive response to slavery. Such an undertaking is congruent with the literary tradition of black American women writers who reimagine "the attitudes and morality of women, men, girls, and boys who chafe at and defy the restrictions imposed by the dominant White capitalist value system" (Cannon, 2003 p. 64). In Jubilee, the Civil War is reconstructed as a black men's opportunity to redefine and affirm their masculinity and humanity through active struggle against the capitalist, patriarchal system of slavery.

Black males' initial involvement in the Civil War sometimes had a paradoxical dimension, because white Southern slaveholders and Confederate Army forced the slaves to contribute their labor for the war effort, which actually was against the slaves' own interest. In the novel, although black males perform laborious activities, risking their lives in varied circumstances, they know their efforts will not lead to liberation. For instance, the Confederates use the black men to make gunpowder, the means employed against those who fight for the slaves' manumission.

This work was hot [...] so they worked stripped naked to the waist with noise and fire as their constant companions. If a slave were not careful, unskilled and unaccustomed as he was to such work, he might lose a hand and then he was no longer good for the job (Walker, 1999, p. 211). 


\section{Agnieszka Łobodziec - Black Masculinity and Plantation}

However, no matter how confining the circumstances are, the slaves seek to find opportunities to resist the 'watchful eye' of the oppressive overseer. Even though "shackled in iron and heavily guarded for the journey" (ibid.) towards munitions works, some prisoners on the work gangs manage to escape. Learning of the Union Army, some of them seek to join it in order to fight for their own freedom.

The black character Jim's initial participation in the Civil War also exemplifies the paradoxical nature of the war. He accompanies his master John Dutton, an avid Confederate soldier. When Dutton is severely wounded on the battlefield, his slave Jim experiences conflicting emotions. On the one hand, remembering the hostility of plantation patriarchy, he seeks to break free from the Duttons' plantation. On the other hand, he is "tied to a strange code of honor, duty, and noblesse oblige which he could not have explained" (ibid., p. 220-221). Therefore, as a committed servant, he takes his wounded master back to the plantation. He also approaches the war with ambiguous feelings. Violence and guns terrify him, but at the same time thoughts of freedom inspire him. Participation in the Civil War enables him to learn more of the state's political condition. The role and mission of the Union Army are made known to him. He witnesses the ardent freedom attempts of black people. He saw "crowds of Negroes fleeing from the plantations, hiding in the woods and swamps and mountains while gangs of them were guerillas in the country and camping on the roadsides and in the foothills" (ibid., p. 220). Jim, however, instead of joining the resisting black troops, felt an inexplicable call to assist his master. Nevertheless, although Jim treats his enemy humanely, Jim is aware that he could never "settle down again into the routine of the plantation" (ibid., p. 237).

Other black men succeed in joining the Union Army, which enrages white Confederate soldiers, who curse when they see black men fighting against them as equal soldiers. Some black men reveal their rage on the battlefield, where they finally can stand face to face with the southern white man, their real enemy. Theirs is a killing rage, expressed mercilessly. Margaret Walker hyperbolically presents the intensity of this rage through a deadly scene in which a black soldier kills Kevin, a white soldier, John Dutton's cousin, who, paradoxically, sees violence and war as unnecessary. Happy to live until the last day of his obligatory military mission, and 
hoping to join his beloved family in due time, Kevin fearlessly participates in a battle. Unexpectedly, he is dispatched by a black soldier.

Suddenly he stumbled and looked up in the face of a huge black Negro. The soldier had his bayonet pointed at Kevin but what surprised Kevin most was the look of hatred on the black man's face. Kevin raised his own bayonet to protect himself and strike at the same time. As he plunged it into the Negro's groin, he felt the pain of a stabbing knife in his own abdomen and twisting against it he grabbed the other man's gun while turning loose his own. His assailant fell back with a cry of pain, and Kevin struggled in his own mortal agony to pull the blade out of his stomach. (ibid., p. 249)

The scene of a black man and a white man in mortal combat on the battlefield pinpoints the historically and politically conditioned animosity between them. At the same time, it implies that the white oppressor is confronted on equal basis. The white man's attitude towards the war and violence and his search for peaceful conflict resolution have no bearing. The black man sees him as the enemy that must be dealt with in pursuance of the black freedom struggle. The white man, in turn, uses violent selfdefense, a means he previously refuted.

Eventually, black men in a large number begin to flee the Southern plantations ruled by white patriarchal oppressors. The Union Army offers a most promising alternative, although racial equality is denied to the runaway slaves. Initially, they are even exploited. Nevertheless, although black men perform the same backbreaking work in the Union Army as that on the plantation, it now seems more bearable because they labor for their own freedom. The following passage relates the nature of black people's flight from the South and the role of black men in the Union Army:

[...] the year 1863 saw a wholesale disappearance of the black people from the southern plantations. Thousands of them were fleeing to the protection of the Union armies. They left the hoe in the field. They left the making of the guns and gunpowder in the factories. They fled from the Confederate fortifications and breastworks for the southern army. The whole work force of the southern states went on a general strike. And what the black slaves 
had done for the Confederacy under bondage they now did for the Union free of charge, for there was little pay or compensation they could gain from anything they did. It was enough to be free. Freedom from chattel bondage filled the Negro people with exultation, with praise to God, and thanks to Mr. Lincoln, the Moses who had come. For Mr. Lincoln had certainly changed his mind about the black man. (ibid., p. 246)

As evidenced here, black men seek to affirm their manhood as freedom fighters, by choosing to escape from plantation. They work as men motivated by the hope of future advancement and not as a resignedly dehumanized labor force exploited for the benefit of an oppressive master.

Finally, after the Civil War, the black men can establish their own patriarchal households. In Jubilee, Margaret Walker portrays black men who regard having their own family as a primary objective after the Emancipation Proclamation. In his forties, Jim, a houseboy at the Duttons' plantation, reunites with his beloved May Liza, and they both leave the Big House in order to start a family life in freedom. Another character, Innis Brown, encourages Vyry, whose husband has not returned from the war, to leave the plantation and marry him. To Innis, lonely and homeless, she seems a perfect marital prospect. She already has two children, for whom he could be a loving father. He develops a particular close relationship with Vyry's son, Jimmy. He feels almost like a family protector, keeping an eye on Vyry's cabin. He offers to do so because it is dangerous for a single black woman with two children to live alone on a plantation, which most men have vacated. Even before Innis and Vyry leave the plantation, they cooperatively divide family gender roles between them. She proves to be a skillful and resourceful housewife, capable of preparing delicious meals, making soap from grease and wood ashes, making candles from tallow, and weaving and making warm winter clothes. Innis hunts in order to provide food. He seeks to become a self-sufficient and independent man as he declares, "I wants to work for myself. I ain't a slave no more [...] and I wants to work for myself" (ibid., p. 301). Eventually, he convinces Vyry to marry him, which she does only because of her common sense. Innis, however, is not much concerned about Vyry's emotional coolness towards the marriage. He is more "excited" and "jubilant" (ibid., p. 307) because he can at last be a real family man. 
Historically, three major responses of the enslaved black men to slavery have been discerned:

cooperation, covert aggression, and rebellion. The cooperative slave was faithful and obedient, tended to identify with his master, and sought to please him. Most of the slaves, whose lot was very hard, felt hostile and bitter and, whole they feared the consequences of open rebellion, showed their anger and aggression in passive or roundabout ways. The third group includes slaves who refused to allow themselves to be used. They fought the system by sabotage, self-mutilation, flight or revolt. (Nichols, 1972, p. 15).

Regarding the literary portrayal of the aforementioned responses, Margaret Walker's Jubilee depicts primarily the last two. The passive response of black male characters constitutes silent repression of their rage. The fear of white male punishment stymies black men's resistance. As the character Jim in Margaret Walker's Jubilee manifests, the outcome of such passivity is hopelessness and powerlessness. The rebellion, in turn, involves Randall Ware's attempt to establish his family life and to be a family provider and his and other black men's confrontation of their white oppressors on the battlefield during The Civil War.

\section{Conclusions}

In Jubilee, Margaret Walker portrays the interconnectedness between plantation patriarchy and the etiology of black American men's redefinition of masculinity.

The novel constitutes the fusion of documented historical data and the writers' imagination. Referring to a number of essential documental materials in the form of, for instance, historical accounts, slave narratives, newspaper articles that she managed to collect before writing Jubilee, Walker states,

I had only to give my material the feel of a fabric of life. At this point I seemed to have a vision of the whole artistic task before me - the creation of fiction from fact, the development of imagined clothing, of muscle and flesh for the real and living bones of history (1990, p. 58). 
This approach to writing evidences Walker's concern with an artistic imagination that envisions the interior lives of people who existed during the sparsely documented historical period of slavery. The novelist reconstructs considerable interiority through imagining the black men's emotions that surfaced under oppressive circumstances.

The image of the Big House, the surrounding husbandry, and plantation represent white male pride and sense of supremacy over black enslaved males. If white male overseers are at the lower level of the social ladder, they seek to emulate slaveholders. As far as the black men are concerned, their emotional state is affected by the response to the oppressive patriarchal realm, which forces a redefinition of manhood. Black manhood is reconstructed as a twofold ideal, comprising the affirmation of two inseparable components - mainly humanity and masculinity. All the black male characters are placed in milieus dominated by white males, who define what a successful man in America means. Practically, "[i]f masculinity could only be achieved by protecting and providing for one's family, then under this system black men could never be "real' man" (Hooks, 2003 p. 126). Black men, deprived of the rights and means to fully realize these patriarchal ideals, manifest a range of emotions in their confrontation with white males. A black free man, Randall Ware, though not fully recognized by the mainstream society, expresses positive selfesteem and hope for future advancement. In contradistinction, Margaret Walker also portrays black men who suppress their emotions as a survival strategy. Some black characters, as a result of their inability to protect black women "from the sexual advance of white men" (Green, 2009, p. 5), to resist exploitation at the hands of white slaveholders, to establish their own loving families, and to govern their own lives, submerge themselves in hopelessness and powerlessness. Finally, it is the Civil War that truly facilities black men's hope for masculine affirmations.

\section{References}

Ash, S. V. (2010). The black experience in the Civil War South. Santa Barbara: Praeger. 
Cannon, K. G. (2003). Katie's canon: Womanism and the soul of the black community. New York: Continuum.

Fox-Genovese, E. (1988). Within the plantation household: Black and white women of the South. Chapel Hill and London: University of North Carolina Press.

Green, T. T. (2009). A fatherless child: Autobiographical perspectives on African American men. Columbia; London: University of Missouri Press.

Hine, D. C. (1996). Speak truth to power: Black professional class in United States history. Brooklyn, N.Y.: Carlson Pub.

Hooks, B. (2003). Rock my soul: Black people and self-esteem. New York: Atria Books.

Hooks, B. (2004). We real cool: Black men and masculinity. New York and London: Routledge.

Nichols, C. H. (1972). Black men in chains: Narratives by escaped slaves. New York: Lawrence Hill and Co.

Parker, C. S. (2009). Fighting for democracy: Black veterans and the struggle against white supremacy in the postwar South. Princeton: Princeton University Press.

Thompson, E. T. (1975). Plantation societies, race relations, and the South: The regimentation of populations. Durham, N.C.: Duke University Press.

Walker, M. (1990). How I wrote Jubilee. In M. Graham (Ed.) How I wrote Jubilee and other essays on life and literature. New York: Feminist Press at the City University of New York.

Walker, M. (1999). Jubilee. Boston and New York: A Mariner Book.

Agnieszka Lobodziec, PhD, is Assistant Professor and the Head of the Section of Literature of the English Speaking World, English Department, University of Zielona Gora, Poland.

Contact Address: Direct correspondence to Agnieszka Łobodziec, Faculty of Humanities, al. Wojska Polskiego 71a, 65-762 Zielona Gora, Poland, email: agat47@yahoo.com 